Check for updates

Cite this: RSC Adv., 2019, 9, 128

Received 30th November 2018 Accepted 17th December 2018

DOI: 10.1039/c8ra09861a

rsc.li/rsc-advances

\title{
Anti-phytopathogenic sesquiterpenoid-xanthone adducts from potato endophytic fungus Bipolaris eleusines $\uparrow$
}

\author{
Juan He, ${ }^{a}$ Man-Si Yang, ${ }^{a}$ Wen-Xiang Wang, ${ }^{\mathrm{b}}$ Zheng-Hui Li, ${ }^{a}$ \\ Waill Ahmed Mohamed Elkhateeb, ${ }^{d}$ Ting-Chi Wen, ${ }^{\star c}$ Hong-Lian Ai ${ }^{\star a b}$ \\ and Tao Feng $(\mathbb{D}$ *a
}

A bioguided separation on the cultures of the potato endophytic fungus Bipolaris eleusines led to the isolation of two anti-phytopathogenic (Alternaria solani) sesquiterpenoid-xanthone adducts, namely bipolins I and $J$ ( 1 and 2). Their structures were established via extensive spectroscopic analysis. Compounds 1 and 2 exhibit potent inhibitory activity against $A$. solani with MIC values of 8 and $16 \mu \mathrm{g}$ $\mathrm{mL}^{-1}$, respectively.

\section{Introduction}

Sativene sesquiterpenoids usually feature an unusual $5 / 6$ or $5 / 7$ bridged ring system, ${ }^{1-4}$ which attracted great interest in total synthesis ${ }^{5-8}$ and biological studies., ${ }^{2,8-10}$ Our previous investigations on the potato endophytic fungus Bipolaris eleusines reported bipolenins $\mathrm{A}-\mathrm{H},{ }^{11-13}$ and indicated that the fungus is a good resource for sativene sesquiterpenoids. Some of them show cytotoxicities to human cancer cell lines and inhibitory activity on nitric oxide production. Our recent studies found that the potato endophytic fungus $B$. eleusines can inhibit the growth of potato pathogen Alternaria solani (early blight) on PDA (Fig. 1), which suggested the metabolites from the fungus may possess good inhibitions on the plant pathogen. This discovery prompted us to search for anti-pathogenic agents from the endophytic fungus $B$. eleusines. Therefore, a bioguided isolation on the cultures of the fungus B. eleusines was carried out. As a result, two novel sativene sesquiterpenoid-xanthone adducts, namely bipolenins I and J (1 and 2, Fig. 2), were obtained from liquid fermentation of the fungus. Their structures were established via extensive spectroscopic analyses. Pure compounds $\mathbf{1}$ and $\mathbf{2}$ were evaluated for their inhibitory activities

${ }^{a}$ School of Pharmaceutical Sciences, South-Central University for Nationalities, Wuhan 430074, China. E-mail: 2015050@mail.sucuec.edu.cn; tfeng@mail.scuec.edu.cn

${ }^{b}$ School of Agriculture and Biological Technic, Yunnan Agricultural University, Kunming 650201, China

'The Engineering Research Center of Southwest Bio-Pharmaceutical Resources, Ministry of Education, Guizhou University, Guiyang 550025, China. E-mail: tingchiwen@yahoo.com

${ }^{d}$ Department of Chemistry of Microbial Natural Products, National Research Center, Dokki, Giza 12311, Egypt

$\dagger$ Electronic supplementary information (ESI) available. See DOI: $10.1039 / \mathrm{c} 8 \mathrm{ra09861a}$ on A. solani. Herein the isolation, structural elucidation, and bioactivity of compounds $\mathbf{1}$ and $\mathbf{2}$ are reported.

\section{Results and discussion}

Bipolenin I (1) had a molecular formula $\mathrm{C}_{31} \mathrm{H}_{36} \mathrm{O}_{9}$ as determined on the basis of the positive HRESIMS, which showed a molecular ion peak at $\mathrm{m} / \mathrm{z} 575.2250[\mathrm{M}+\mathrm{Na}]^{+}$(calcd for $\mathrm{C}_{31} \mathrm{H}_{36} \mathrm{O}_{9} \mathrm{Na}$, 575.2252), corresponding to seven degrees of unsaturation. The UV data at $329 \mathrm{~nm}$ indicated a highly conjugated system, while the IR absorption bands at 3440 and $1745 \mathrm{~cm}^{-1}$ suggested the existence of hydroxy and carbonyl, respectively. The ${ }^{1} \mathrm{H}$ and ${ }^{13} \mathrm{C}$ NMR spectra, in association with the HSQC spectrum, revealed six methyl (one methoxy), four methene, nine methine, and twelve quaternary carbons (Table 1). Preliminary analysis on the NMR data, a possible moiety of sativene sesquiterpenoid was detected by comparison the data with those our reported previously. ${ }^{1,2,4,11-13}$ As shown in unit A of Fig. 3, a long spin system was obtained by analysis of the ${ }^{1} \mathrm{H}^{-1} \mathrm{H}$

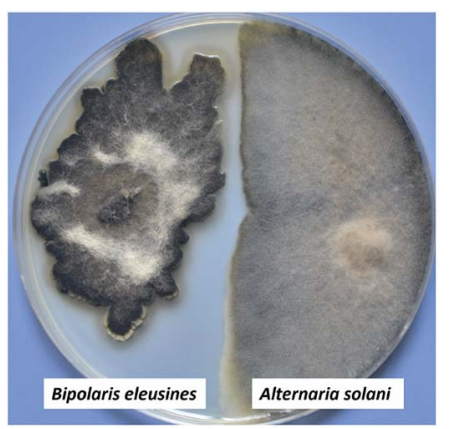

Fig. 1 The growth inhibition of potato endophytic fungus $B$. eleusines against potato pathogen Alternaria solani on PDA. 


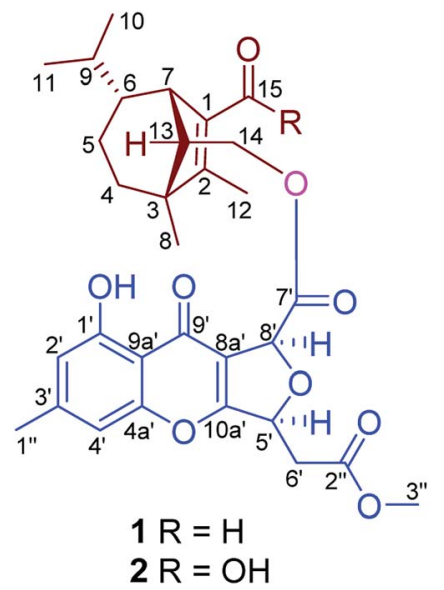

Fig. 2 Structures of bipolenins I and J ( 1 and 2 ) from cultures of the fungus Bipolaris eleusines.

COSY spectrum. A methyl substituted 1,2-double bond-15aldehyde moiety was established by the ${ }^{13} \mathrm{C}$ NMR data at $\delta_{\mathrm{C}}$ 137.2 (s, C-1), 164.9 (s, C-2), 187.9 (d, C-15), and 10.6 (q, C-12), and supported by HMBC correlations from $\delta_{\mathrm{H}} 10.00(\mathrm{~s}, \mathrm{H}-15)$ and $2.01(3 \mathrm{H}, \mathrm{s}, \mathrm{H}-12)$ to $\mathrm{C}-1$ and $\mathrm{C}-2$. This moiety was connected by bonds of $\mathrm{C}-1 / \mathrm{C}-7$ and $\mathrm{C}-2 / \mathrm{C}-3$ as deduced from HMBC correlations from $\delta_{\mathrm{H}} 3.11(1 \mathrm{H}$, br s, $\mathrm{H}-7)$ to $\mathrm{C}-2$, and from $\mathrm{H}-12$ to an $\mathrm{sp}^{3}$ quaternary carbon at $\delta_{\mathrm{C}} 50.9$ (s, C-3). In addition, a singlet at $\delta_{\mathrm{H}} 1.05(3 \mathrm{H}, \mathrm{s}, \mathrm{H}-8)$ for a methyl group showed HMBC correlations to $\mathrm{C}-3, \mathrm{C}-2$, and to other two carbon resonances at $\delta_{\mathrm{C}} 33.8(\mathrm{~d}, \mathrm{C}-4)$ and $57.5(\mathrm{~d}, \mathrm{C}-13)$. These data, as well as other HMBC correlations (Fig. 3), suggested that unit A was a sativene sesquiterpenoid related to helminthosporol. ${ }^{\mathbf{1 , 4}}$ In unit B (Fig. 3), a four-substituted benzene ring was identified by two aromatic protons at $\delta_{\mathrm{H}} 6.68\left(1 \mathrm{H}, \mathrm{s}, \mathrm{H}-2^{\prime}\right)$ and $6.74\left(1 \mathrm{H}, \mathrm{s}, \mathrm{H}-4^{\prime}\right)$. A methyl and a hydroxy as two substituents in the benzene ring were identified by the HMBC correlations as shown in Fig. 3. Analysis of UV data and the chemical shifts at $\delta_{\mathrm{C}} 178.0$ (s, C-9'), $114.5\left(\mathrm{~s}, \mathrm{C}-8 \mathrm{a}^{\prime}\right), 167.5\left(\mathrm{~s}, \mathrm{C}-10 \mathrm{a}^{\prime}\right)$ suggested the existence of a chromone core of unit $\mathrm{B}$. Due to the existence of an intramolecular hydrogen bond, the proton of the hydroxy group appeared as a singlet at $\delta_{\mathrm{H}} 12.09\left(\mathrm{~s}, \mathrm{OH}-1^{\prime}\right)$, which further confirmed the existence of the chromone core. The ${ }^{1} \mathrm{H}-{ }^{1} \mathrm{H}$ COSY spectrum revealed a short spin system of $\mathrm{CH}\left(5^{\prime}\right)-\mathrm{CH}_{2}\left(6^{\prime}\right)$, which

Table $1{ }^{1} \mathrm{H}(500 \mathrm{MHz})$ and ${ }^{13} \mathrm{C}(125 \mathrm{MHz}) \mathrm{NMR}$ data of 1 and 2 in $\mathrm{CDCl}_{3}(\delta$ in ppm, $\mathrm{J}$ in $\mathrm{Hz})$

\begin{tabular}{|c|c|c|c|c|}
\hline \multirow[b]{2}{*}{ No. } & \multicolumn{2}{|l|}{1} & \multicolumn{2}{|l|}{2} \\
\hline & $\delta_{\mathrm{C}}$ & $\delta_{\mathrm{H}}$ & $\delta_{\mathrm{C}}$ & $\delta_{\mathrm{H}}$ \\
\hline 1 & $137.2, \mathrm{~s}$ & & $125.5, \mathrm{~s}$ & \\
\hline 2 & $164.9, \mathrm{~s}$ & & $161.3, \mathrm{~s}$ & \\
\hline 3 & $50.9, \mathrm{~s}$ & & $50.5, \mathrm{~s}$ & \\
\hline 4 & $33.8, \mathrm{t}$ & $1.38, \mathrm{~m}$ & $33.6, \mathrm{t}$ & $1.34, \mathrm{~m}$ \\
\hline $5 a$ & $25.0, \mathrm{t}$ & $1.72, \mathrm{~m}$ & $24.9, \mathrm{t}$ & $1.71, \mathrm{~m}$ \\
\hline $5 b$ & & $0.84, \mathrm{~m}$ & & $0.97, \mathrm{~m}$ \\
\hline 6 & $44.6, \mathrm{~d}$ & $0.98, \mathrm{~m}$ & $44.9, \mathrm{~d}$ & $0.96, \mathrm{~m}$ \\
\hline 7 & $41.7, \mathrm{~d}$ & 3.11 , br s & $43.6, d$ & 3.10, br s \\
\hline 8 & $18.4, \mathrm{q}$ & $1.05, \mathrm{~s}$ & $18.9, \mathrm{q}$ & $1.00, \mathrm{~s}$ \\
\hline 9 & $31.5, \mathrm{t}$ & $0.97, \mathrm{~m}$ & $31.5, \mathrm{~d}$ & $1.17, \mathrm{~m}$ \\
\hline 10 & $20.6, \mathrm{q}$ & $0.71, \mathrm{~s}$ & $20.8, \mathrm{q}$ & $0.74, \mathrm{~d}(6.5)$ \\
\hline 11 & $21.3, \mathrm{q}$ & $0.95, \mathrm{~s}$ & $21.4, \mathrm{q}$ & $0.93, \mathrm{~d}(6.5)$ \\
\hline 12 & $10.6, \mathrm{q}$ & $2.01, \mathrm{~s}$ & $12.5, \mathrm{q}$ & $2.00, \mathrm{~s}$ \\
\hline 13 & $57.5, \mathrm{~d}$ & $1.81, \mathrm{dd}(8.6,5.6)$ & $58.0, \mathrm{~d}$ & $1.79, \mathrm{dd}(8.3,5.5)$ \\
\hline $14 \mathrm{a}$ & $65.8, \mathrm{t}$ & 4.21 , dd $(11.1,5.6)$ & $66.0, \mathrm{t}$ & 4.26 , dd $(11.2,5.5)$ \\
\hline $14 \mathrm{~b}$ & & 3.89 , dd $(11.1,5.6)$ & & 3.94 , dd $(11.2,8.3)$ \\
\hline 15 & 187.9, d & $10.00, \mathrm{~s}$ & 168.6, s & \\
\hline $1^{\prime}$ & $160.9, \mathrm{~s}$ & & $160.9, \mathrm{~s}$ & \\
\hline $2^{\prime}$ & $113.5, \mathrm{~d}$ & $6.68, \mathrm{~s}$ & $113.5, \mathrm{~d}$ & 6.66 , br s \\
\hline $3^{\prime}$ & $147.4, \mathrm{~s}$ & & $147.4, \mathrm{~s}$ & \\
\hline $4^{\prime}$ & $107.9, \mathrm{~d}$ & $6.74, \mathrm{~s}$ & $107.9, \mathrm{~d}$ & 6.73, br s \\
\hline $4 a^{\prime}$ & $157.2, \mathrm{~s}$ & & $157.2, \mathrm{~s}$ & \\
\hline $5^{\prime} \mathrm{a}$ & $78.0, \mathrm{~d}$ & 5.69, ddd $(6.3,4.3,4.0)$ & $78.0, \mathrm{~d}$ & 5.70, ddd $(6.4,4.3,4.0)$ \\
\hline $5^{\prime} \mathrm{b}$ & & & & \\
\hline $6^{\prime} \mathrm{a}$ & $37.6, \mathrm{t}$ & 2.97, dd $(16.0,4.3)$ & $37.6, \mathrm{t}$ & 2.97, dd $(16.1,4.3)$ \\
\hline $6^{\prime} \mathrm{b}$ & & 2.82, dd $(16.0,6.3)$ & & 2.82, dd $(16.1,6.4)$ \\
\hline $7^{\prime}$ & $169.4, \mathrm{~s}$ & & $169.5, \mathrm{~s}$ & \\
\hline $8^{\prime}$ & $79.4, \mathrm{~d}$ & $5.58, \mathrm{~d}(4.0)$ & $79.4, \mathrm{~d}$ & $5.60, \mathrm{~d}(4.0)$ \\
\hline $8 a^{\prime}$ & 114.5, s & & $114.6, \mathrm{~s}$ & \\
\hline $9^{\prime}$ & $178.0, \mathrm{~s}$ & & $177.9, \mathrm{~s}$ & \\
\hline $9 a^{\prime}$ & 108.9, s & & $108.9, \mathrm{~s}$ & \\
\hline $10 a^{\prime}$ & $167.5, \mathrm{~s}$ & & $167.5, \mathrm{~s}$ & \\
\hline $1^{\prime \prime}$ & $22.3, \mathrm{q}$ & $2.41, \mathrm{~s}$ & $22.3, \mathrm{q}$ & $2.40, \mathrm{~s}$ \\
\hline $2^{\prime \prime}$ & $169.3, \mathrm{~s}$ & & 169.3, s & \\
\hline OMe & $52.2, \mathrm{q}$ & $3.73, \mathrm{~s}$ & $52.2, \mathrm{q}$ & $3.73, \mathrm{~s}$ \\
\hline $1^{\prime}-\mathrm{OH}$ & & 12.09, s & & $12.10, \mathrm{~s}$ \\
\hline
\end{tabular}




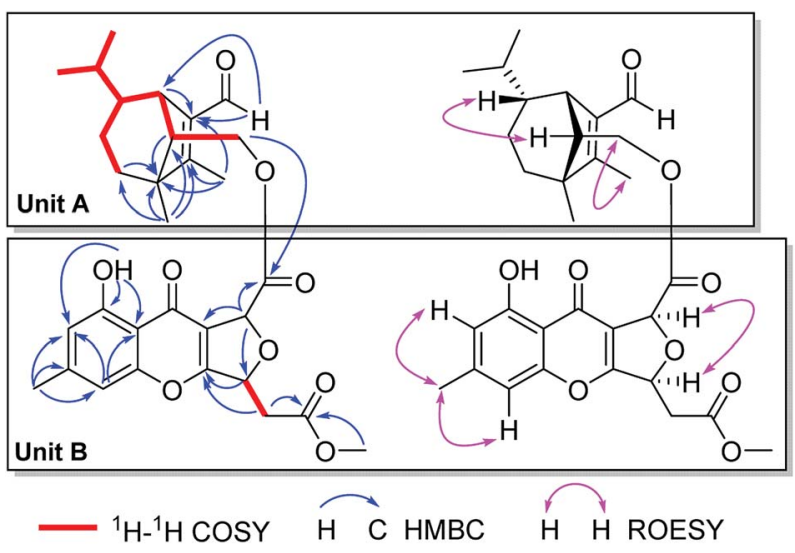

Fig. 3 Key 2D NMR correlations of 1 .

connected to a methyl ester group as established by the HMBC correlations from $\delta_{\mathrm{H}} 2.97\left(1 \mathrm{H}, \mathrm{dd}, J=16.0,4.3 \mathrm{~Hz}, \mathrm{H}-6^{\prime} \mathrm{a}\right), 2.82$ $\left(1 \mathrm{H}, \mathrm{dd}, J=16.0,4.3 \mathrm{~Hz}, \mathrm{H}-6^{\prime} \mathrm{b}\right)$ and $3.73(3 \mathrm{H}, \mathrm{s}, \mathrm{OMe})$ to $\delta_{\mathrm{C}} 169.3$ (s, C-2"). The spin system also connected to C-10a' based on the HMBC correlation from $\delta_{\mathrm{H}} 5.69(1 \mathrm{H}, \mathrm{ddd}, J=6.3,4.3,4.0 \mathrm{~Hz}, \mathrm{H}-$ $\left.5^{\prime}\right)$ to $\mathrm{C}-10 \mathrm{a}^{\prime}$. So far, only two carbons including a methine $(\mathrm{CH}-$ $\left.8^{\prime}\right)$ and a carbonyl carbon at $\delta_{\mathrm{C}} 169.4\left(\mathrm{~s}, \mathrm{C}-7^{\prime}\right)$ were left. Further analysis of HMBC spectrum, the correlations from $\delta_{\mathrm{H}} 5.88(1 \mathrm{H}$, $\left.\mathrm{d}, J=4.0 \mathrm{~Hz}, \mathrm{H}-8^{\prime}\right)$ to $\mathrm{C}-7^{\prime}, \mathrm{C}-8 \mathrm{a}^{\prime}$, and $\mathrm{C}-5^{\prime}$ suggested that $\mathrm{C}-8^{\prime}$ was connected to $\mathrm{C}-8 \mathrm{a}^{\prime}$ and $\mathrm{C}-\mathrm{7}^{\prime}$, respectively, and an ether bond was established between $\mathrm{C}-5^{\prime}$ and $\mathrm{C}-8^{\prime}$. The unit $\mathrm{B}$ was, therefore, identified as a seco-xanthone related to a synthetic product in the literature. ${ }^{14}$ The connection by an ester bond between units A and B was revealed by an HMBC correlation from $\mathrm{H}-14$ to $\mathrm{C}-7^{\prime}$, as well as analysis of the MS data. An ROESY experiment was carried out to establish the relative configuration of $\mathbf{1}$ (Fig. 3). In unit A, a cross peak between $\mathrm{H}-6$ and $\mathrm{H}-13$ suggested that $\mathrm{H}-6$ and $\mathrm{H}-13$ were in the same side. Another cross peak between $\mathrm{H}-12$ and $\mathrm{H}-14$ confirmed the relative configuration of $\mathrm{C}-13$ as shown. In unit $\mathrm{B}$, a key cross peak between $\mathrm{H}-5^{\prime}$ and $\mathrm{H}-\mathrm{8}^{\prime}$ indicated that $\mathrm{H}-5^{\prime}$ and $\mathrm{H}-8^{\prime}$ were in the same side, while the cross peaks of $\mathrm{H}-1^{\prime \prime} / \mathrm{H}-4^{\prime}$ and $\mathrm{H}-1^{\prime \prime} / \mathrm{H}-2^{\prime}$ helped with the position identification of substituents in the benzene ring. The structure of 1 was, finally, established as depicted.

Compound 2 was isolated as a light yellow gum. Its molecular formula $\mathrm{C}_{31} \mathrm{H}_{36} \mathrm{O}_{10}$ was determined by an HRESIMS ion peak at $m / z 567.2240[\mathrm{M}-\mathrm{H}]^{-}$(calcd for $\mathrm{C}_{31} \mathrm{H}_{35} \mathrm{O}_{10}, 567.2236$ ), 16 unit more than that of 1 . All the spectroscopic data of 2 displayed almost the same patterns to those in 1, except that a carboxyl signal at $\delta_{\mathrm{C}} 168.6(\mathrm{~s}, \mathrm{C}-15)$ in the ${ }^{13} \mathrm{C}$ NMR of 2 replaced the aldehyde signal at $\delta_{\mathrm{C}} 187.9$ in that of 1 . It was supported by an HMBC correlation from $\delta_{\mathrm{H}} 3.10(1 \mathrm{H}, \mathrm{br} \mathrm{s}, \mathrm{H}-7)$ to $\mathrm{C}-15$, while the other parts of 2 were elucidated as the same to those of 1 by detailed analysis of 2D NMR data. The structure of 2 was established, and named as bipolenin $\mathrm{J}$.

Compounds $\mathbf{1}$ and $\mathbf{2}$ were evaluated for their antiphytopathogenic activities against four plant pathogens including Phytophthora infestane, Alternaria solani, Rhizoctonia solani, and Fusarium oxysporum. As a result (Table 2), compounds 1 and 2 all exhibited potent inhibitory activity
Table 2 Inhibitions of 1 and 2 on four phytopathogens $\left(\mu \mathrm{g} \mathrm{mL}^{-1}\right.$ )

\begin{tabular}{lllll}
\hline Comps & P. infestans & A. solani & R. solani & F. oxysporum \\
\hline $\mathbf{1}$ & NA & 8 & NA & 64 \\
$\mathbf{2}$ & NA & 16 & NA & NA \\
Hygromycin B $^{a}$ & 8 & $<4$ & 8 & 64 \\
${ }^{a}$ Positive control; NA: no activity. & &
\end{tabular}

against A. solani with MIC values of 8 and $16 \mu \mathrm{g} \mathrm{mL}{ }^{-1}$, respectively. While compound 1 also weakly inhibited $F$. oxysporum with an MIC values of $64 \mu \mathrm{g} \mathrm{mL} \mathrm{m}^{-1}$.

\section{Conclusions}

In summary, two novel sesquiterpenoid-xanthone adducts, bipolenins I and J, were obtained from potato endophytic fungus Bipolaris eleusines by a bioguided isolation. The potent inhibitory activities of $B$. eleusines and its metabolites on phytopathogens revealed a possible application prospect on biological pesticide for B. eleusines.

\section{Experimental section}

\section{General experimental procedures}

The melting points were tested by a Putiantongchuang WRX-5A apparatus. Optical rotations were measured on a Jasco-P-1020 polarimeter. IR spectra were obtained by using a Bruker Tensor 27 FT-IR spectrometer with KBr pellets. NMR spectra were acquired with instrument of a Bruker DRX-500. HSESIMS was measured on an API QSTAR Pulsar spectrometer. Silica gel (200-300 mesh, Qingdao Marine Chemical Inc., China) and Sephadex LH-20 (Amersham Biosciences, Sweden) were used for column chromatography (CC). Fractions were monitored by TLC (Qingdao Marine Chemical Inc., China) and spots were visualized by heating silica gel plates immersed in vanillin$\mathrm{H}_{2} \mathrm{SO}_{4}$ in EtOH, in combination with Agilent 1200 series HPLC system (Eclipse XDB-C18 column, $5 \mu \mathrm{m}, 4.6 \times 150 \mathrm{~mm}$ ). Preparative HPLC was performed on an Agilent 1100 series with a Zorbax SB-C18 $(5 \mu \mathrm{m}, 9.4 \times 150 \mathrm{~mm})$ column.

\section{Fungal material and cultivation conditions}

The fungus Bipolaris eleusines was isolated from fresh potatoes sampled from the nursery of Yunnan Agricultural University at random in July 2012. The fungus was identified by observing the morphological characteristics and analysis of the internal transcribed spacer (ITS) regions (max identity: 99\%; query cover: 98\%; accession: KJ909768.1). The strain is deposited at South-Central University for Nationalities, China (No. PE20120728-SCUN-201603).

This fungal strain was cultured on potato dextrose agar (PDA) medium at $24{ }^{\circ} \mathrm{C}$ for 10 days. The agar plugs were inoculated in $500 \mathrm{~mL}$ Erlenmeyer flasks, each containing $100 \mathrm{~mL}$ of potato dextrose media. Flask cultures were incubated at $28{ }^{\circ} \mathrm{C}$ on a rotary shaker at $160 \mathrm{rpm}$ for two days as seed culture. One hundred and twenty $500 \mathrm{~mL}$ Erlenmeyer flasks each containing 
$150 \mathrm{~mL}$ of potato dextrose broth (PDB) were individually inoculated with $25 \mathrm{~mL}$ of seed culture, and were incubated at $25{ }^{\circ} \mathrm{C}$ on a rotary shaker at $160 \mathrm{rpm}$ for 20 days.

\section{Extraction and isolation}

A total of $20 \mathrm{~L}$ culture broth was extracted three times with EtOAc. The organic layer was evaporated to give a crude extract (15 g). The crude extract was subjected to silica gel CC (200-300 mesh) eluted with a $\mathrm{CHCl}_{3}-\mathrm{MeOH}$ solvent system (a gradient from $1: 0$ to $0: 1)$ to afford seven fractions A-G. Fraction C (1.2 $\mathrm{g})$ was further separated by silica gel CC eluted with petroleum ether- $\mathrm{Me}_{2} \mathrm{CO}(12: 1)$ to afford subfractions C1-C6. Fraction C2 (90 mg) was isolated by Sephadex $\mathrm{LH}-20 \mathrm{CC}(\mathrm{MeOH})$ and by $\mathrm{HPLC}\left(\mathrm{MeCN}-\mathrm{H}_{2} \mathrm{O}\right.$, from $3: 7$ to $6: 4$ in $\left.25 \mathrm{~min}, 10 \mathrm{~mL} \mathrm{~min}^{-1}\right)$ to give $1(4.2 \mathrm{mg})$ and $2(3.5 \mathrm{mg})$.

Bipolenin I (1). Yellow oil; $[\alpha]_{\mathrm{D}}^{21.7}+81.3(c=0.2, \mathrm{MeOH}) ; \mathrm{UV}$ $(\mathrm{MeOH}) \lambda_{\max }(\log \varepsilon) 203.0$ (3.65), 250.5 (3.66), 329 (2.88) nm; IR $(\mathrm{KBr}) \nu_{\text {max }}: 3440,2924,1745,1661,1635,1619,1462,1383$, $1208 \mathrm{~cm}^{-1}$; ${ }^{1} \mathrm{H}$ NMR $\left(500 \mathrm{MHz}, \mathrm{CDCl}_{3}\right)$ and ${ }^{13} \mathrm{C} \mathrm{NMR}(125 \mathrm{MHz}$, $\mathrm{CDCl}_{3}$ ) data, see Table 1 , HRESIMS $m / z$ 575.2250 $[\mathrm{M}+\mathrm{Na}]^{+}$ (calcd for $\mathrm{C}_{31} \mathrm{H}_{36} \mathrm{O}_{9} \mathrm{Na}, 575.2252$ ).

Bipolenin J (2). Light yellow gum; $[\alpha]_{\mathrm{D}}^{21.5}+22.0(c=0.08$, $\mathrm{MeOH}) \mathrm{UV}(\mathrm{MeOH}) \lambda_{\max }(\log \varepsilon) 203$ (3.53), 246 (3.52), 329.5 (2.58), 382.5 (2.37) nm; IR (KBr) $\nu_{\max } 3441,2923,1740,1632$, 1462, 1384, 1206, $1061 \mathrm{~cm}^{-1} ;{ }^{1} \mathrm{H}$ NMR (500 MHz, $\left.\mathrm{CDCl}_{3}\right)$ and ${ }^{13} \mathrm{C}$ NMR (125 MHz, $\mathrm{CDCl}_{3}$ ) data, see Table 1, HRESIMS $\mathrm{m} / \mathrm{z}$ 567.2240 $[\mathrm{M}-\mathrm{H}]^{-}$(calcd for $\mathrm{C}_{31} \mathrm{H}_{35} \mathrm{O}_{10}, 567.2236$ ).

\section{Anti-phytopathogenic assay}

Compounds $\mathbf{1}$ and $\mathbf{2}$ were subjected to minimal inhibitory concentration (MIC) tests against four phytopathogenic fungi (Phytophthora infestane, Alternaria solani, Rhizoctonia solani, Fusarium oxysporum) on the PDA medium using a twofold serial dilution in the microplate wells over the range of 4-256 $\mu \mathrm{g}$ $\mathrm{mL}^{-1}$. To this end, into each well of 96 well plate was placed 80 $\mu \mathrm{L}$ of PDA along with a $20 \mu \mathrm{L}$ volume of an aqueous test sample solution. The test solutions held different concentrations of the sample being tested. The control well held $80 \mu \mathrm{L}$ PDA and $20 \mu \mathrm{L}$ of sterile water. Then, agar plugs $\left(1 \mathrm{~mm}^{3}\right)$ with fresh phytopathogens were inoculated into each well. Observations of the plates were made after $24 \mathrm{~h}$ of incubation at $26{ }^{\circ} \mathrm{C}$ in order to acquire the MICs with no growth in the well taken as that value. Three replicates were maintained to confirm the antifungal activity.

\section{Conflicts of interest}

There are no conflicts to declare.

\section{Acknowledgements}

This work was financially supported by the National Natural Science Foundation of China (31560010, 81872762, 31870513) and the Fundamental Research Funds for the Central University, South-Central University for Nationalities (CZT18014, CZT18013). The authors thank the Analytical \& Measuring Center of Kunming Institute of Botany, CAS for the spectral test.

\section{Notes and references}

1 S. Tamura, A. Sakurai, K. Kainuma and M. Takai, Agric. Biol. Chem., 1963, 27, 738-739.

2 P. de Mayo and R. E. Williams, J. Am. Chem. Soc., 1965, 87, 3275.

3 F. Dorn and D. Arigoni, Experientia, 1974, 30, 851-852.

4 C. Osterhage, G. M. König, U. Höller and A. D. Wright, J. Nat. Prod., 2002, 65, 306-313.

5 G. L. Hodgson, D. F. MacSweeney and T. Money, J. Chem. Soc., Perkin Trans. 1, 1973, 19, 2113-2130.

6 P. Bakuzis, O. O. S. Campos and M. L. F. Bakuzis, J. Org. Chem., 1976, 41, 3261-3264.

7 S. Karimi, J. Nat. Prod., 2001, 64, 406-410.

8 A. Khanum Shaukath, S. Shashikanth, G. Sathyanarayana Syagadadu, S. Lokesh and A. Deepak Saligrama, Pest Manage. Sci., 2009, 65, 776-780.

9 H. Miyagawa, S. Nagai, T. Tsurushima, M. Sato, T. Ueno and H. Fukami, Biosci., Biotechnol., Biochem., 1994, 58, 11431145.

10 J. K. Park, K. Hasumi and A. Endo, J. Antibiot., 1993, 46, 1303-1305.

11 H. L. Ai, M. S. Yang, S. H. Zi and H. C. Guo, J. Asian Nat. Prod. Res., 2015, 17, 982-987.

12 M. S. Yang, X. Y. Cai, Y. Y. He, M. Y. Lu, S. Liu, W. X. Wang, Z. H. Li, H. L. Ai and T. Feng, Nat. Prod. Bioprospect., 2017, 7, 147-150.

13 Z.-H. Li, H.-L. Ai, M.-S. Yang, J. He and T. Feng, Phytochem. Lett., 2018, 27, 87-89.

14 T. Sassa, H. Kachi and M. Nukina, J. Antibiot., 1985, 38, 439441. 